\title{
Cytotoxic Activity of Pentacyclic Triterpene-3-Heptadecanoate Ester against Hela Cell Line and Its Docking Study
}

\author{
Sri Mulyani Mulyadi ${ }^{1}$, Tri Yuliati², Maulana Tegar' ${ }^{1}$, dan Imam Ardhila ${ }^{1}$ \\ ${ }^{1}$ Faculty of Pharmacy, Universitas Gadjah Mada, Yogyakarta \\ ${ }^{2}$ LPPT, Universitas Gadjah Mada, Yogyakarta \\ Korespondensi: Sri Mulyani Mulyadi \\ Email: srimulyanijogja@gmail.com
}

\begin{abstract}
Pentacyclic triterpene-3-heptadecanoate (12,13-dihydro- $\alpha$-amyrin-20,30-en-3-heptadecanoate) ester refers to the compound as a result of reaction between pentacyclic triterpene-3-ol (12,13-dihydro- $\alpha$-amyrin-20,30-en-3-ol) and heptadecanoic acid. This research was aimed to conduct cytotoxicity test of pentacyclic triterpene-3-heptadecanoate; 12,13-dihydro- $\alpha$-amyrin-20,30-en-3-ol and 12,13-dihydro- $\alpha$-amyrin-20,30-en-3-acetate esters against Hela cell line. The activity assay was carried out using MTT method. The results indicated that $I C_{50}$ value of $12,13-d i h y d r o-\alpha$-amyrin-3heptadecanoate; 12,13-dihydro- $\alpha$-amyrin-20,30-en-3-acetate and 12,13-dihydro- $\alpha$-amyrin-20,30-en-3ol were 111.0, 151.1 and $944.4 \mu \mathrm{g} / \mathrm{ml}$, respectively. The compound of 12,13-dihydro- $\alpha$-amyrin-20,30en-3-heptadecanoate had the lowest $I C_{50}$ value, suggesting it has a potency to be synthesized as an anticancer drug.
\end{abstract}

Keywords: Hela cells line; pentacyclic triterpene-3-heptadecanoate ester; 12,13-dihydro- $\alpha$-amyrin-20,30en- $\alpha$-amyrin-3-ol; 12,13-dihydro- $\alpha$-amyrin-20,30-en-3-acetate ester; cytotoxic activity 


\section{Introduction}

Cancer is a disease that cause the loss of cell control towards both the regulation of cell cycle and homeostatic function leading to fast and uncontrolled proliferation [1]. A number of researchs have been conducted to create new anticancer compound. Isolation of natural substances known to have anticancer activity have also been conducted. By finding the lead compound having some activities as anticancer, therefore, the chemical groups playing a role of having corresponding activities can be determined. This, as a result, offers an opportunity to modify a lead compound in order to find a new more potential compound. The natural compounds useful as the anticancer are 12,13-dihydro- $\alpha$-amyrin-20,30en-3-ol and 12,13-dihydro- $\alpha$-amyrin-20,30-en3 -acetate that are categorized as the pentacyclic triterpenes.

Pentacyclic triterpene-3-heptadecanoate ester (Figure 1) is the compound as the result of the synthesis of pentacyclic triterpene-3-ol and heptadecanoic acid [2]. 12,13-dihydro- $\alpha$-amyrin20,30-en-3-ol (pentacyclic triterpene) is also present in the Eupatorium inulifolium H.B.K leaves. Compound that can be isolated from $E u$ patorium inulifolium is 12,13 -dihydro- $\alpha$-amyrin20,30-en-3-acetate [3]. Mulyadi [4], reported that 12,13-dihydro- $\alpha$-amyrin-20,30-en-3-ol and 12,13-dihydro- $\alpha$-amyrin-20,30-en-3-acetate are useful as inhibitors of protein kinase enzyme target in Hela cells (cervix cancer cell) in vitro, meaning to have the cytotoxic activity. 12,13-dihydro- $\alpha$-amyrin-20,30-en-3-acetate (es- ter with $\mathrm{C} 1$ ) has $\mathrm{IC}_{50}$ value of $268.8 \mu \mathrm{g} / \mathrm{ml}$ while 12,13-dihydro- $\alpha$-amyrin-20,30-en-3-ol has $\mathrm{IC}_{50}$ value of $628.9 \mu \mathrm{g} / \mathrm{ml}$. [Figure 1]

Based on the calculation of the molecular docking score with the PLANTS program [5] towards the protein kinase enzyme target (code 3HMP), the result of the docking of pentacyclic triterpene ester with C9 was as much as $(-80,7)$, C14 (-84, $3)$, C16 $(-88,5)$ and C15 $(-87,9)$. From those results, the pentacyclic triterpene ester with $\mathrm{C} 16$ was chosen to be tested its cytotoxic activity in which the pentacyclic triterpene ester with C16 was as the pentacyclic triterpene-3-heptadecanoate ester that was possible to be more active than the pentacyclic triterpene-3-acetate ester. The selection of Hela cell line for the research was because it was in line with the purpose to be applied to human.

Some problems emerging from this research included how the cytotoxic activity of the triterpene pentacyclic-3-heptadecanoate ester (C16) and whether it is more effective compared to the pentacyclic triterpene-3-acetate ester (C1). Thus, the objective of this research is to find out the cytotoxic activity of triterpene pentacyclic-3-heptadecanoate ester as the anticancer towards Hela cell line. Hela cell line is cervix cancer cell that can be used for cancer research [6].

\section{Methods}

\subsection{Instrument and materials}

Laminar air flow cabinet (Labcono), 96-well microplate (Nucleon), eppendorf, Elisa reader (BioRad mode 680), incubator $\mathrm{CO}_{2}$ (Labcono),

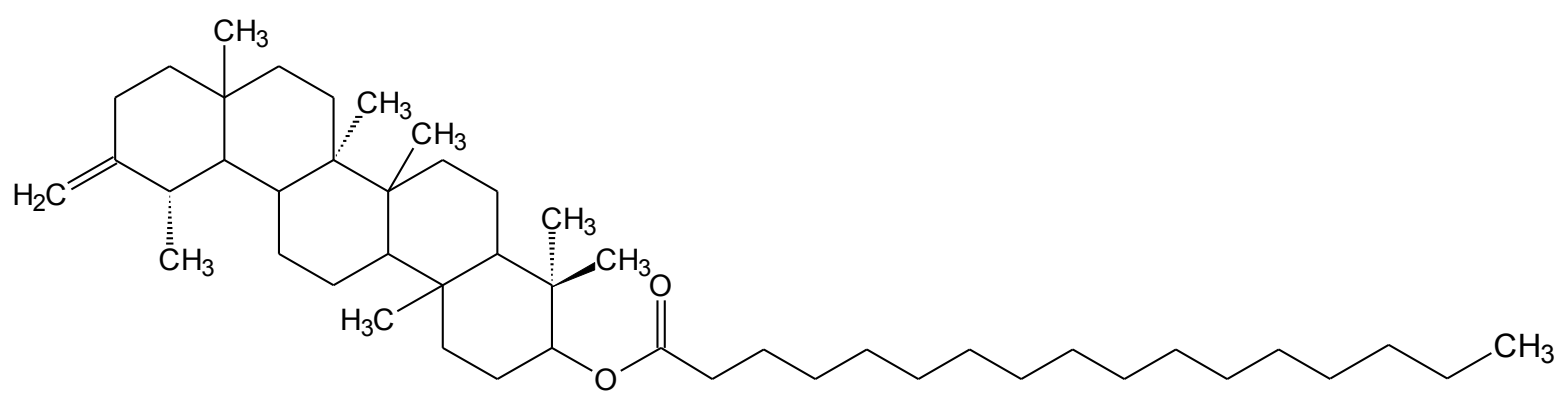

Figure 1. Structure of triterpene pentacyclic-3-heptadecanoate ester 
centrifuge (PLC 01), pipette, tissue culture flask, vortex (Thermolyne Maximi), micropipette (Finnipipet Campus), refrigerator, Nebauer haemocytometer, analytical scale, camera and a set of computer for docking.

The materials used are pentacyclic triterpene3-acetate, pentacyclic triterpene-3-ol, pentacyclic triterpene-3-heptadecanoate ester (result of esterification), MTT, Phosphate Buffered Saline (PBS), Natrium Dodecyl Sulphate (SDS) and Hydrochloride Acid ( $\mathrm{HCl}$ ). Hela cell line was obtained from LPPT UGM (Laboratory of Integrated Research and Testing of Universitas Gadjah Mada).

\subsection{Cytotoxicity test}

Stock solution of 12,13-dihydro- $\alpha$-amyrin20,30-en-3-heptadecanoate was prepared by dissolving in dimethyl sulfoxide (DMSO) and media culture of RPMI 1640 was initially done in order to obtain a series of concentration from 15.6 to 500 $\mu \mathrm{g} / \mathrm{ml}$. The 12,13-dihydro- $\alpha$-amyrin-20,30-en-3acetate and 12,13-dihydro-amyrin-20,30-en-3-ol was also prepared in the series of concentration from 15.6 to $500 \mu \mathrm{g} / \mathrm{ml}$. The Hela cell line with concentration of 20,000 cells/well were placed into 96-well plates containing RPMI 1640 with the volume of $100 \mu \mathrm{l} /$ well were incubated within 1 day. A series of concentrations of pentacyclic triterpene-3-heptadecanoate ester were placed into the $100 \mu \mathrm{l}$ wells. Here, triterpene pentacyclic triterpene -3-heptadecanoate ester had a series of concentrations of $15.6,31.3,62.5,250$ and 500 $\mu \mathrm{g} / \mathrm{ml}$. Then, it was incubated within 24 hours in an incubator with $5 \% \mathrm{CO}_{2}$ at the temperature of $37^{\circ} \mathrm{C}$. MTT with the concentration of $5 \mathrm{mg} / \mathrm{ml}$ in PBS was added to this compound before the compound was placed into each of $10-\mu \mathrm{l}$ well and incubated for 4 hours in an incubator with 5\% $\mathrm{CO}_{2}$ at $37^{\circ} \mathrm{C}$. The stop solution of $10 \%$ SDS in hydrochloride acid $0.01 \mathrm{~N}$ at $100 \mu \mathrm{l}$, subsequently, was added and incubated at room temperature. In this case, the absorbance of it was read using Elisa reader with the wavelength of $550 \mathrm{~nm}$.

The $\mathrm{IC}_{50}$ value was obtained from the analysis of regression from the result of absorbance obtained. Based on the equation of $\mathrm{y}=\mathrm{Bx}+\mathrm{A}$ with $\mathrm{x}$ $=$ the level of pentacyclic triterpene-3-heptadecanoate ester, pentacyclic triterpene-3-acetate ester, pentacyclic triterpene-3-ol and $\mathrm{y}=$ mean of the cell viability (\%). Thus, the $\mathrm{IC}_{50}$ could be found by correlating percentage of cell viability at $50 \%$ at the equation. In this case, the $\mathrm{IC}_{50}$ value can be calculated as $\mu \mathrm{g} / \mathrm{ml}$ and then divided with the molecular weight. The calculation of cell viability is as follows:

viability $=\frac{\text { sample } A \mathrm{~b}-\text { media control } A b}{\text { cell control of } A b-\text { media control } A b} \times 100 \%$

Remark: $\mathrm{Ab}=$ absorbance

\section{Results and discussion}

The results of cytotoxicity test of pentacyclic triterpene-3-heptadecanoate ester, pentacyclic triterpene-3-acetate ester and triterpene pentacyclic triterpene-3-ol against the Hela cell line (Table 1, 2, and 3) show that all of the compounds could inhibit the growth of Hela cells line with the $\mathrm{IC}_{50}$ value in the level of $\mu \mathrm{g} / \mathrm{ml}$.

The results of the cytotoxicity test of three pentacyclic triterpene compounds showed effect on the inhibition of the Hela cells' growth. The $\mathrm{IC}_{50}$ value of pentacyclic triterpene-3-heptadecanoate ester, pentacyclic triterpene-3-acetate ester and pentacyclic triterpene-3-ol were 110.0, 151.1 and $944.40 \mu \mathrm{g} / \mathrm{ml}$, respectively. This shows that pentacyclic triterpene-3-heptadecanoate ester as the result of modification had the lowest $\mathrm{IC}_{50}$ value. In other words, esterification of pentacyclic triterpene-3-ol with heptadecanoic acid increased the activity.

The highest concentration of compound selected was $500 \mu \mathrm{g} / \mathrm{ml}$. The relationship between percentage of viability of Hela cell line and the concentration of each compound are shown in Figure 2 .

It can be seen from Figure 2 that the higher the concentration of the compounds, the smaller 
Table 1. The viability test of triterpene pentacyclic-3-heptadecanoate ester (ETPH) against Hela cell line

\begin{tabular}{|c|c|c|c|c|c|c|c|c|}
\hline \multirow{2}{*}{$\begin{array}{l}\text { Concentration of } \\
\text { triterpene pentacyclic- } \\
\text { 3-heptadecanoate } \\
\text { ester }(\mu \mathrm{g} / \mathrm{ml})\end{array}$} & \multicolumn{3}{|c|}{ Absorbance } & \multicolumn{4}{|c|}{ Viability (\%) } & \multirow[b]{2}{*}{$\mathrm{IC}_{50}(\mu \mathrm{g} / \mathrm{ml})$} \\
\hline & 1 & 2 & 3 & 1 & 2 & 3 & Average & \\
\hline 500 & 0.060 & 0.050 & 0.040 & 2.49 & 1.63 & 0.77 & 1.63 & 111.0 \\
\hline 250 & 0.165 & 0.168 & 0.168 & 11.50 & 11.75 & 11.76 & 11.67 & \\
\hline 125 & 0.519 & 0.655 & 0.549 & 41.89 & 53.56 & 44.46 & 46.64 & \\
\hline 62.5 & 0.665 & 0.812 & 0.735 & 54.42 & 67.04 & 60.43 & 60.63 & \\
\hline 31.25 & 0.663 & 0.874 & 0.865 & 54.43 & 72.36 & 71.59 & 66.06 & \\
\hline 15.625 & 0.771 & 0.850 & 0.790 & 63.52 & 70.30 & 65.15 & 66.32 & \\
\hline
\end{tabular}

Table 2. The viability test of triterpene pentacyclic-3-acetate ester (ETPA) against Hela cell line

\begin{tabular}{lcccccrrrr}
\hline $\begin{array}{l}\text { Concentration of } \\
\text { triterpene pentacyclic- } \\
\text { 3-acetate ester }(\boldsymbol{\mu g} / \mathbf{m l})\end{array}$ & \multicolumn{1}{c}{ Absorbance } & $\mathbf{2}$ & $\mathbf{3}$ & \multicolumn{1}{c}{ Viability (\%) } & \multicolumn{1}{c}{$\mathbf{2}$} & $\mathbf{3}$ & Average & IC $\mathbf{5 0}(\boldsymbol{\mu g} / \mathbf{m l})$ \\
\hline 500 & 0.145 & 0.144 & 0.110 & 9.78 & 9.70 & 6.78 & 8.75 & 151.1 \\
250 & 0.452 & 0.421 & 0.427 & 36.14 & 33.48 & 33.99 & 34.53 & \\
125 & 0.748 & 0.661 & 0.730 & 61.54 & 54.08 & 60.00 & 58.54 & \\
62.5 & 0.714 & 0.680 & 0.962 & 58.63 & 55.71 & 79.91 & 64.75 & \\
31.25 & 0.738 & 0.768 & 0.000 & 60.69 & 63.26 & 0.00 & 61.97 & \\
15.625 & 0.789 & 0.673 & 0.808 & 65.06 & 55.11 & 62.29 & 62.29 & \\
\hline
\end{tabular}

Table 3. The viability test of triterpene pentacyclic-3-ol (TPOL) against Hela cell line

\begin{tabular}{|c|c|c|c|c|c|c|c|c|}
\hline \multirow{2}{*}{$\begin{array}{l}\text { Concentration of } \\
\text { triterpene pentacyclic- } \\
3-\mathrm{ol}(\mu \mathrm{g} / \mathrm{ml})\end{array}$} & \multicolumn{2}{|c|}{ Absorbance } & \multicolumn{3}{|c|}{ Viability (\%) } & \multirow[b]{2}{*}{3} & \multirow[b]{2}{*}{ Average } & \multirow{2}{*}{$\mathrm{IC}_{50}(\mu \mathrm{g} / \mathrm{ml})$} \\
\hline & 1 & 2 & 3 & 1 & 2 & & & \\
\hline 500 & 0.785 & 0.730 & 0.706 & 64.72 & 60.00 & 57.94 & 60.89 & 994.4 \\
\hline 250 & 0.864 & 0.760 & 0.810 & 71.50 & 62.57 & 66.87 & 66.98 & \\
\hline 125 & 0.871 & 0.000 & 0.804 & 72.10 & 0.00 & 66.35 & 69.23 & \\
\hline 62.5 & 0.873 & 0.882 & 0.848 & 72.27 & 73.05 & 70.13 & 71.82 & \\
\hline 31.25 & 0.834 & 1.170 & 0.802 & 68.93 & 97.77 & 66.18 & 77.73 & \\
\hline 15.625 & 0.886 & 0.815 & 0.828 & 73.39 & 67.30 & 68.41 & 69.70 & \\
\hline
\end{tabular}

Table 4. The results of the docking score between the triterpene pentacyclic-3-heptadecanoate ester, triterpene pentacyclic-3-acetate ester and triterpene pentacyclic-3-ol ester with the target of protein kinase enzymes (code 3HMP)

\begin{tabular}{ll}
\hline Compounds & Docking score \\
\hline Triterpene pentacyclic-3-heptadecanoate ester & -88.5 \\
Triterpene pentacyclic-3-acetate ester & -64.2 \\
Triterpene pentacyclic-3-ol & -61.2 \\
\hline
\end{tabular}


the percentage of the viability is. It means that the pentacyclic triterpene-3-ol had small effect to the percentage of viability. Moreover, the effect of pentacyclic triterpene-3-heptadecanoate ester on the growth of the Hela cell line at the concentration of $500 \mu \mathrm{g} / \mathrm{ml}$ was $1.63 \%$, whereas at the concentration of $15.6 \mu \mathrm{g} / \mathrm{ml}$ was $66.32 \%$. It means that there was a significant effect of the compound on the viability of Hela cell line.

The results in the docking score (Table 4) between the compounds from the result of modification include pentacyclic triterpene com- pound of 12,13-dihydro- $\alpha$-amyrin-20,30-en-3hepadecanoate (ETPH) and the target of protein kinase enzymes (code 3HMP) at -88.5 as a quite good result in comparison to the compound of pentacyclic triterpene 12,13-dihydro- $\alpha$-amyrin20,30-en-3-acetate (ETPA) at -64.2 and the compound of pentacyclic triterpene 12,13-dihydro- $\alpha$ amyrin-20,30-en-3-ol (TP-ol) at -61.2. The docking result was in line with the result of its cytotoxicity test showing that the $\mathrm{IC}_{50}$ value for the compound of 12,13-dihydro- $\alpha$-amyrin-20,30-enheptadecanoate was the lowest one $(111.0 \mu \mathrm{g} /$
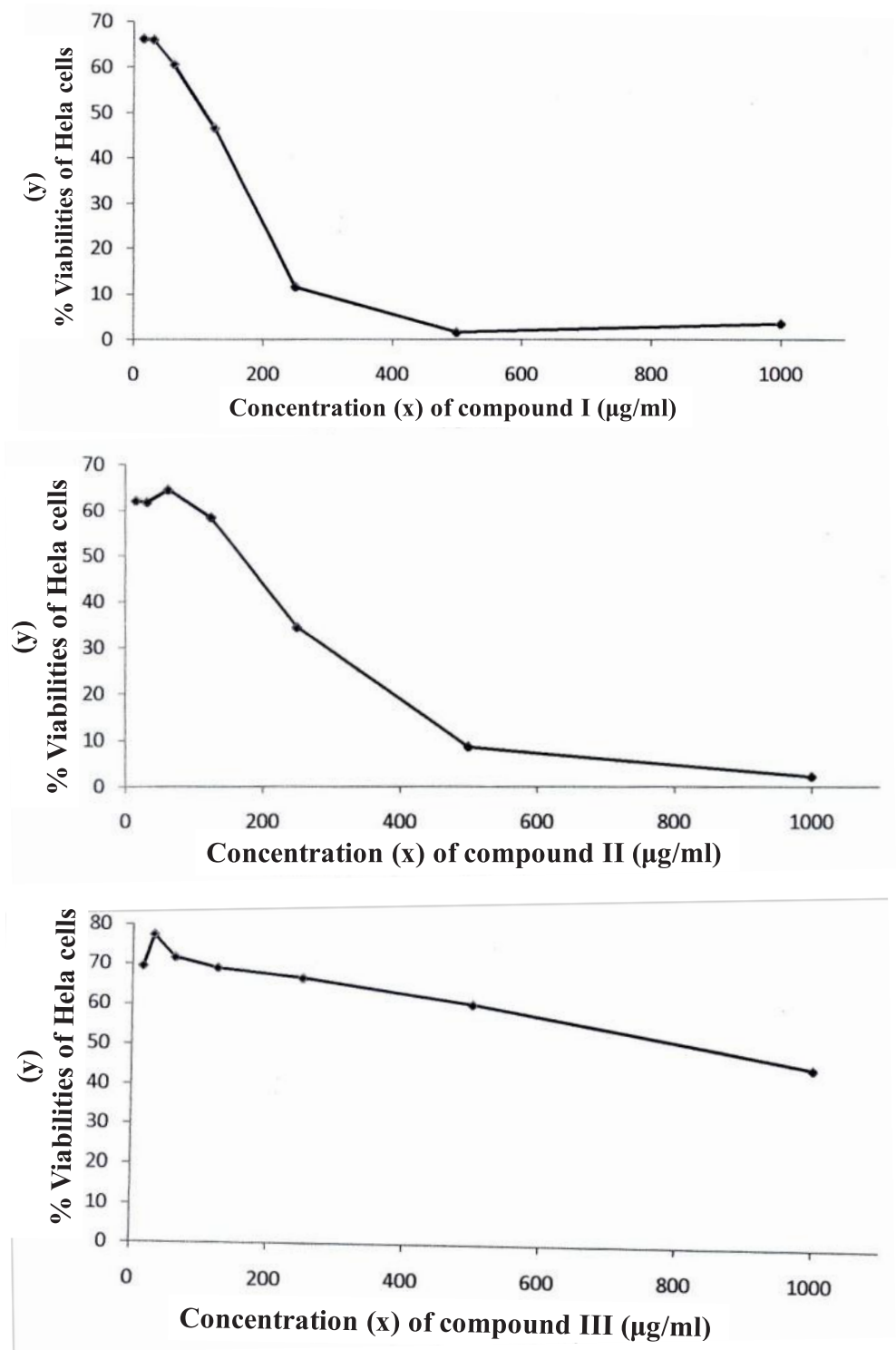

Figure 2. The relationship between percentage of viability (y) of Hela cell line and the concentration (x) of three different compounds $(\mu \mathrm{g} / \mathrm{ml})$

I. Triterpene pentacyclic-3-heptadecanoate ester

II. Triterpene pentacyclic-3-acetate ester

III. Triterpene pentacyclic-3-ol 


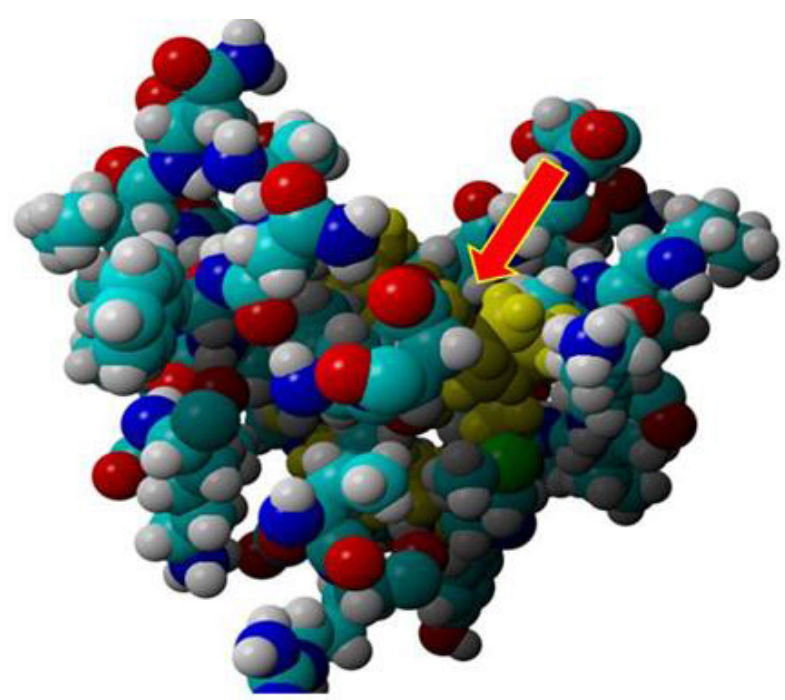

Figure 3. The bond between triterpene pentacyclic-12,13-diydro- $\alpha$-amyrin-20,30-en-3-heptadecanoate ester (ETPH) and the target of protein kinase enzyme (3HMP)

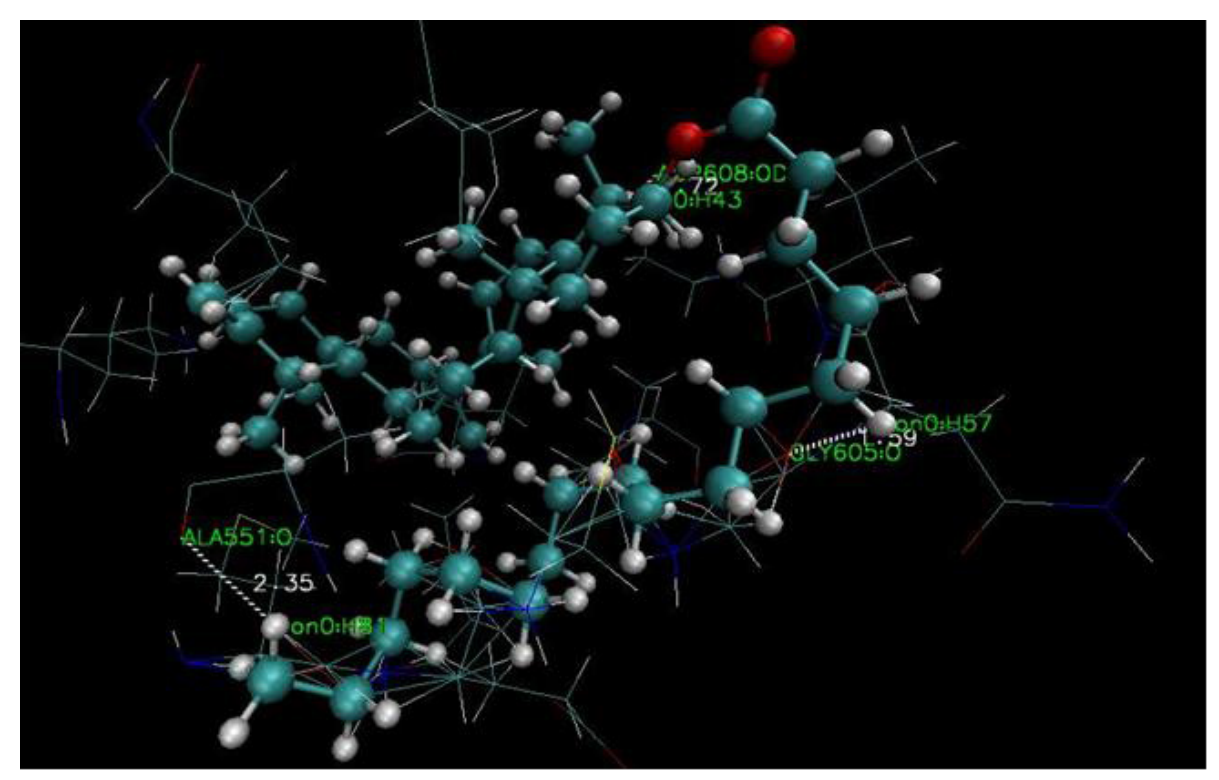

Figure 4. The bond between triterpene pentacyclic-12,13-dihydro- $\alpha$-amyrin-20,30-en-3-heptadecanoate ester (ETPH) and amino acid from the target of protein kinase enzymes (code 3HMP)

$\mathrm{ml}$ ) if it was compared to that of 12,13-dihydro$\alpha$-amyrin-20,30-en-3-acetate $(151.1 \mu \mathrm{g} / \mathrm{ml})$ and 12,13-dihydro- $\alpha$-amyrin-20,30-en-3-ol (944.4 $\mu \mathrm{g} /$ $\mathrm{ml})$. The supports for the result of the docking between the compound of pentacyclic triterpene 12,13-dihydro- $\alpha$-amyrin-20,30-en-3-heptadecanoate with the target of enzymes code of $3 \mathrm{HMP}$ can be seen in Figure 3 and 4.

The results showed a binding between the 12,13-dihydro- $\alpha$-amyrin-20,30-en-3heptadecanoate ester and the target of protein kinase enzyme (code 3HMP) through its binding to Alanin 551 (Ala 551), Glycin 605 (Gly 605) and Aspartate 608 (Asp 608).

\section{Conclusion}

It can be concluded that pentacyclic triterpene-3-heptadecanoate could influence the growth of Hela cell line or it was cytotoxic to the Hela cell line. The $\mathrm{IC}_{50}$ value of pentacyclic 
triterpene-12,13-dihydro- $\alpha$-amyrin-20,30-en3-heptadecanoate ester (ETPH), pentacyclic triterpene-12,13-dihydro- $\alpha$-amirin-20,30-en-3acetate ester and pentacyclic triterpene-12,13dihydro- $\alpha$-amyrin-20,30-en-3-ol were 111.0, 151.1 and $944.4 \mu \mathrm{g} / \mathrm{ml}$, respectively. Those compounds were bound to the target of protein kinase enzymes (code 3HMP) with the docking score $-88.5,-64.2$ and -61.2 , respectively. It was also found that pentacyclic triterpene-12,13dihydro- $\alpha$-amyrin-20,30-en-3-heptadecanoate (ester with C16) was more active than pentacyclic triterpene-12,13-dihydro- $\alpha$-amyrin-20,30en-3-acetate (ester with $\mathrm{C} 1$ ) towards Hela cell line. It also had the most stable binding on target of protein kinase enzyme. Thus, the compound of 12,13-dihydro- $\alpha$-amyrin-20,30-en-3heptadecanoate can be suggested as the anticancer drug to the cervical cancer.

\section{Acknowledgement}

The deepest gratitude is addressed to the Faculty of Pharmacy, UGM that has provided the fund and laboratory facilities. The gratitude is also given to the Head of LPPT Integrated Laboratory of Research and Testing who has allowed conducting the cytotoxicity test to the Hela cell line.

\section{References}

1. Bashar A, Ignacimuthus S, Paulraj G, Al Numair $\mathrm{K}$. Chemopreventive potential of $\beta$-sitosterol in experimental colon cancer model an invitro and invivo study. BMC Complementary and Alternative Medicine. 2010;10(24):1472-6882.

2. Mulyadi SM, Tegar M, Yuliati T, Ardila J. Optimization of ester triterpene pentacyclic-3-acetate from leaves of Eupatorium inulifolium H.B.K., by fibonacci method and infra red spectroscopy identification. Wulfenia Journal. 2013;20(4):216 - 226.

3. Mulyadi SM. Isolasi dan elusidasi struktur kandungan daun Eupatorium inulifolium H.B.K. yang bersifat sitotoksik. Disertasi, Universitas Gadjah Mada, Yogyakarta. 1995.

4. Mulyadi SM. Uji sitotoksisitas tritertepena pentasiklik dari daun Eupatorium inulifolium H.B.K. dengan metode MTT dan studi dockingnya dengan metode Plants. Jurnal Bahan Alam Indonesia. 2011;7(7):387 - 392.

5. Purnomo H. "KIMIA KOMPUTASI: PENAMBATAN MOLEKUL PLANTS”. Yogyakarta: Pustaka Pelajar; 2011.

6. Masters J R. Hela cells 50 years on: The good, the bad and the ugly. Nature Reviews Cancer 2. 2002; 315-319. 